\title{
Landscapes in the Kalahari Gemsbok National Park, South AFrICA
}

\author{
MARGARETHA W. VAN ROOYEN \\ NOEL VAN ROOYEN \\ Department of Plant Science \\ University of Pretoria \\ South Africa \\ JACOBUS DU P. BOTHMA \\ Centre for Wildlife Management \\ University of Pretoria \\ South Africa \\ HENDRIK M. VAN DEN BERG \\ Iris International \\ South Africa \\ Correspondence to: Margaretha W. van Rooyen \\ e-mail: gretel.vanrooyen@up.ac.za
}

Postal Address: Department of Plant Science, University of Pretoria, Pretoria, 0002, South Africa

\begin{abstract}
A landscape map of the Kalahari Gemsbok National Park is presented. Mapping is at a finer scale than previous vegetation and habitat maps for the same area. The landscapes were grouped into seven large classes and a total of 20 landscapes were mapped. A description of the terrain morphology, soil and vegetation of each landscape is provided. Landscapes that are focal points for the large animals of the region include the calcrete outcrops, riverbeds and pans. These landscapes cover only about $10 \%$ of the total area of the region. This map can be used as basis for park planning, management, research and other applications.
\end{abstract}

Keywords: Arid savanna, dune vegetation, Kgalagadi, shrubby grassland, vegetation map

The classification, description and mapping of plant communities and their associated abiotic features are vital first steps in building a framework to understand, protect, conserve and manage our natural resources. Mapping of physiographicphysiognomic relatively homogeneous spatial landscape units at an appropriate scale is therefore a basic requirement for objective resource assessment of any study area. Such a landscape map can amongst others be used to determine the geographical distribution and extent of different habitats; identify areas that are ecologically sensitive (disturbed or high in diversity); assess diversity and the status of rare and endemic species; provide a baseline for assessing range condition and grazing and browsing capacities; interpret animal movements and distribution; and position roads, lodges, hiking and offroad trails.

The vegetation of the southern Kalahari as defined by Thomas and Shaw (1991), or parts thereof, has been described by Pole-Evans (1936), Acocks (1953), Story (1958), Brynard (1958), Leistner (1959a, 1959b, 1967), Giess (1971), Mostert et al. (1971), Bothma and De Graaff (1973), Leistner and Werger (1973), Coetzee and Werger (1975), Werger and Coetzee (1978), Gubb (1980), Werger (1986), Van Rooyen et al. (1988), Van Rooyen (1996) and Van Rooyen and Van Rooyen (1998). Interestingly, the vegetation of the Kalahari Gemsbok National Park (KGNP) was not included in the vegetation map of South Africa compiled by Acocks in 1953. In the refined mapping of the vegetation of South Africa (Low \& Rebelo 1998), seven vegetation types were distinguished and mapped for the southern Kalahari savanna in South Africa of which two occurred within the boundaries of the park, i.e. the Thorny Kalahari Dune Bushveld and the Shrubby Kalahari Dune Bushveld. In the latest vegetation map of South Africa (Mucina et al. 2005, Mucina \& Rutherford 2006), seven vegetation types were identified in the KGNP. These seven types are the Nossob Bushveld, Gordonia Kameeldoring
Bushveld, Gordonia Duneveld, Auob Duneveld, Southern Kalahari Mekgacha, Gordonia Plains Shrubland and Southern Kalahari Salt Pans.

Three phytosociological studies have been conducted in the KGNP. The first classification was done by Leistner and Werger (1973) and 12 plant communities were distinguished and described but not mapped. They concluded that the pattern of the plant communities was determined by soil characteristics, such as soil-water regime and nutrient availability (Werger 1986). In 1999, Lubbinge (1999) did a more detailed study and distinguished 24 plant communities in the KGNP, which he combined into 14 mapping units. Van Rooyen (2000) expanded Lubbinge's floristic analysis to include the entire Kgalagadi Transfrontier Park. In the resultant vegetation map nine vegetation units were confined to the Botswana side of the Kgalagadi Transfrontier Park and 14 units were mapped for the South African side (KGNP) (Van Rooyen 2000).

Bothma and De Graaff (1973) produced the first habitat map of the KGNP. Six major habitat categories were distinguished, viz. the riverbeds of the Auob and Nossob rivers; pans; tree savanna; dunes with tree- or shrub-covered crests; dunes superficially devoid of trees and shrubs; and flat, open grassy plains.

The main objective of the current project was to produce a more detailed map of the KGNP that could be used for park planning and management. Such a map can be used to aid in the selection of sites for vegetation monitoring and serve as a basis to determine animal-habitat relationships. It can also be related to many other ecological spatial data sets, and by so doing it will help to identify knowledge gaps so that efforts to acquire additional data can be prioritised and coordinated. The units identified in the present study were termed landscapes following the definition of Gertenbach (1983): "A landscape is 


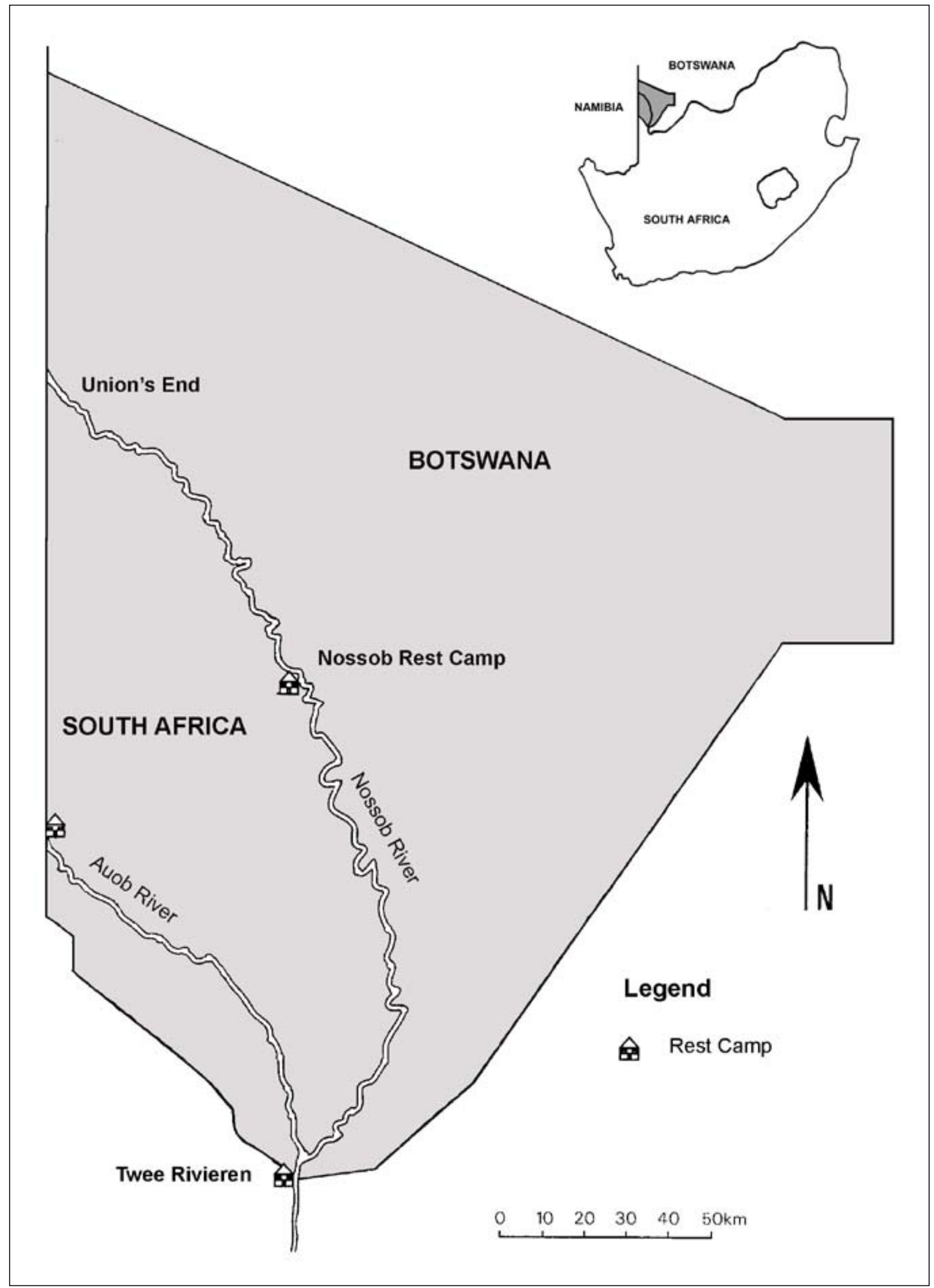

FIGURE 1 


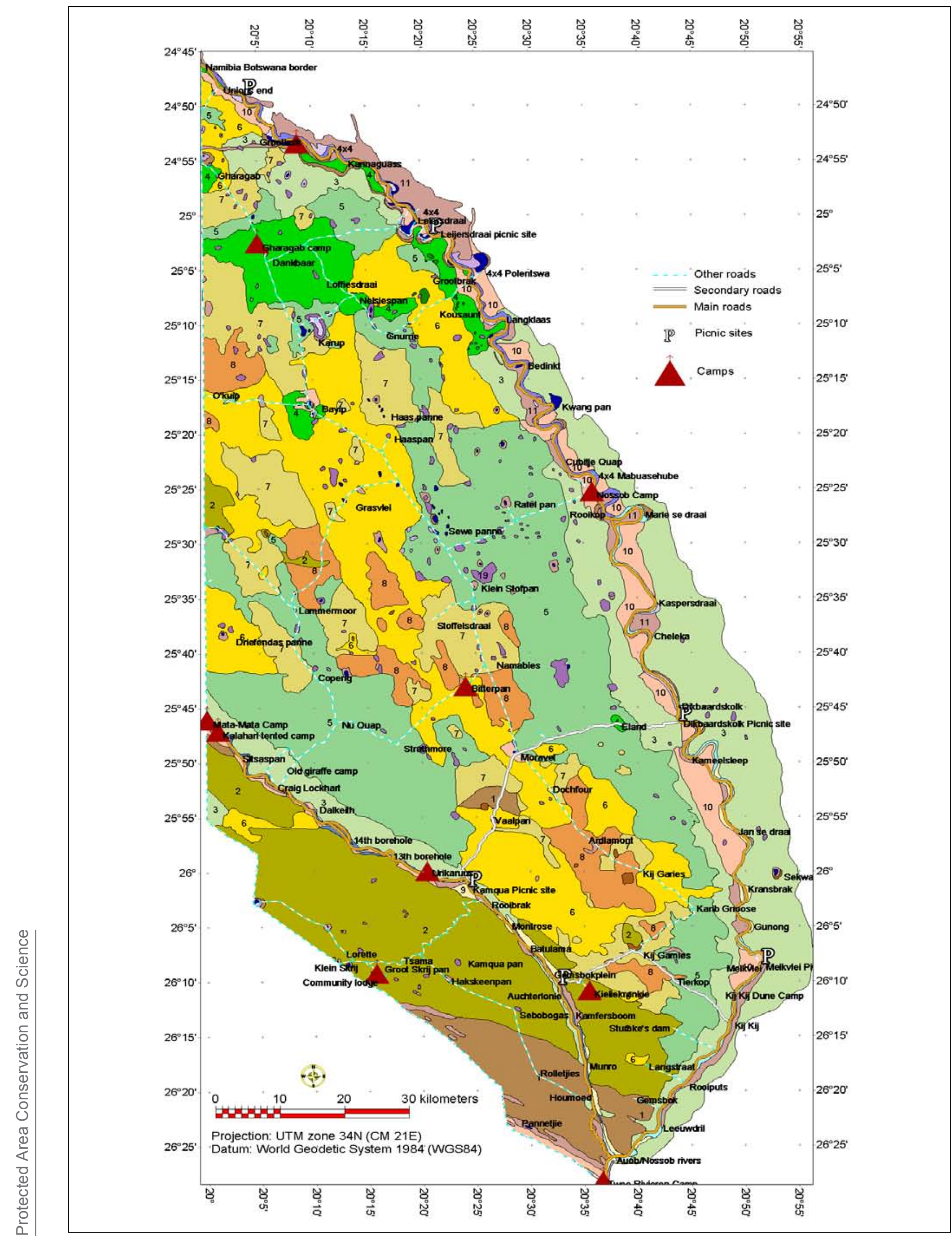

FIGURE 2

Landscapes of the Kalahari Gemsbok National Park 


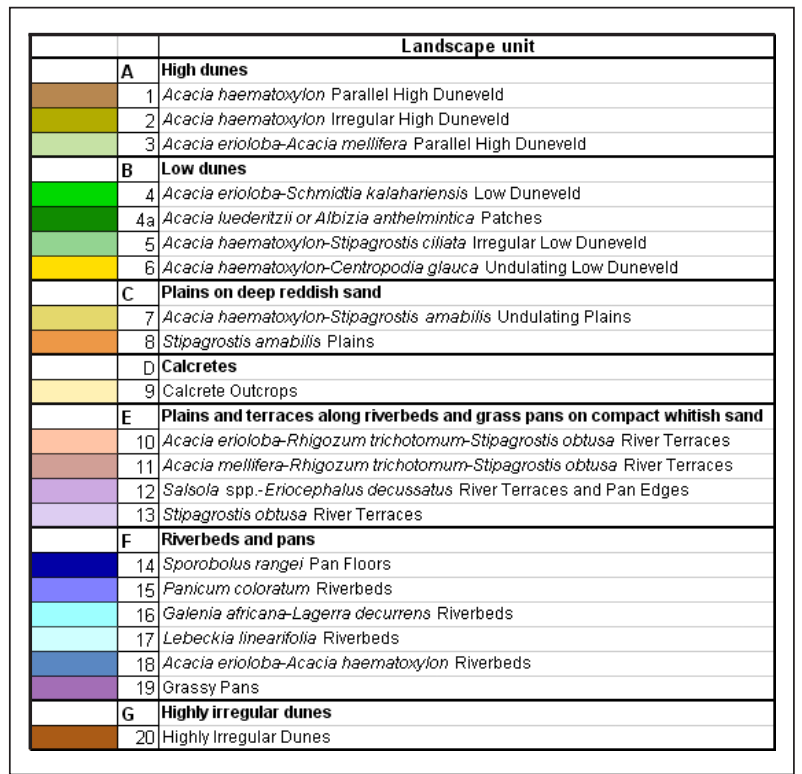

FIGURE 2 (CONT...)

an area with a specific geomorphology, macroclimate, soil and vegetation pattern and associated fauna".

\section{STUDY AREA}

The study area comprises the South African portion of the Kgalagadi Transfrontier Park (Fig. 1), as well as a narrow zone along the eastern side of the Nossob River in Botswana. The mapped area covers approximately $10932 \mathrm{~km}^{2}$. The southern Kalahari is a summer rainfall region and the mean annual rainfall ranges from $150 \mathrm{~mm}$ in the southwest to $450 \mathrm{~mm}$ in the northeast in Botswana. In the study area the mean annual rainfall ranges from approximately $185 \mathrm{~mm}$ to $230 \mathrm{~mm}$. Rainfall is highly erratic (Skarpe 1986, Tyson 1986) and at any specific locality in the park can vary from less than $100 \mathrm{~mm}$ up to more than $700 \mathrm{~mm}$ per annum. The highest rainfall occurs in the four months January to April, with a peak in March. Temperatures show a large amplitude with winter lows reaching $-10.3^{\circ} \mathrm{C}$ and summer highs reaching $45.4^{\circ} \mathrm{C}$ (Van Rooyen et al. 1990).

\section{METHODS}

Stratification and interpretation of the area was done with Landsat ETM satellite images (Bands 4, 5 and 3 [R,G,B]) 1:5000 orthophoto maps and previous habitat and/or vegetation maps and/or descriptions produced by Leistner (1967), Bothma and De Graaff (1973), Leistner and Werger (1973), Skarpe (1986), Bothma and Swart (1990), Bothma et al. (1993), Van Rooyen and Van Rooyen (1998), Lubbinge (1999) and Van Rooyen (2000).

In addition to the floristic data of more than 500 phytosociological relevés, qualitative vegetation and habitat surveys were conducted throughout the park based on the stratification of the available imagery. The data collected at each sample site were a global positioning system (GPS) coordinate, terrain morphology, soil type, soil texture, soil colour, dominant plant species and vegetation structure.

\section{RESULTS}

The southern Kalahari environment is relatively homogeneous because of the predominance of the sand mantle covering the area. The differences between the landscape units that were distinguished in this study are therefore often subtle. The same plant species occur in most of the units, and the differences between the units can often only be ascribed to terrain morphology, e.g. dune height and pattern, or soil characteristics, which relate to soil-water and nutrient supply (Werger 1986), or changes in the dominance and structure of the plant species. The landscapes and their associated vegetation identified in Fig. 2 were grouped into seven large classes and a total of 20 landscapes were mapped (Table 1). A key has been provided in the form of a dendrogram (Fig. 3) that can be used to classify landscapes in the field. An overview of the main corresponding vegetation units in the latest vegetation map of South Africa (Mucina \& Rutherford 2006) is provided in Fig. 4. In general, the mapping units of Mucina and Rutherford are heterogeneous assemblages compared to the units presented here.

An electronic ArcView-compatible version (raster or vector format) of the landscape map is available from the authors on request. A printable version at a scale of 1:150 000 when printed to media $841 \mathrm{~mm}$ by $1400 \mathrm{~mm}$ is also available. The pdf version provided here should best be printed to $\mathrm{A} 3$.

\section{A. High dunes \\ 1. Acacia haematoxylon Parallel High Duneveld}

These grass-covered, relatively parallel (linear) high dunes occupy an area of 40951 ha (3.75\% of the mapped area; Fig. 2) and occur in the south in the vicinity of Twee Rivieren. Fig. 5a illustrates the parallel (linear) dunes that are up to $20 \mathrm{~m}$ in height in this unit. The coarse, red, loose sand of the dune crests is dominated by the tall grass Stipagrostis amabilis while the shrub Acacia haematoxylon is the most conspicuous and widespread woody species on the grassy dunes and in the valleys. Besides Stipagrostis amabilis, the other prominent grass species are Schmidtia kalahariensis, Centropodia glauca, Eragrostis trichophora, E. lehmanniana, Brachiaria glomerata and Stipagrostis uniplumis. The most common dwarf shrubs or forbs include Hermannia tomentosa, Plinthus sericeus, Requienia sphaerosperma, Bulbostylis hispidula, Limeum arenicolum, Oxygonum dregeanum and Sesamum triphyllum. The prostrate creepers Acanthosicyos naudinianus and Citrullus lanatus may be seasonally prominent on exposed dune crests. In isolated patches within this landscape unit, the shrub Lebeckia linearifolia is a prominent species found on dunes near pans and rivers.

\section{Acacia haematoxylon Irregular High Duneveld}

This extensive dune landscape (Fig. 5b) occurs south of the Auob River and between the Nossob and Auob rivers in the south and occupies an area of 127532 ha ( $11.67 \%$ of the mapped area). The unit is characterised by scattered Acacia haematoxylon trees and shrubs, while the presence of Boscia albitrunca and Acacia mellifera differentiates this unit from the previous one. The prominent grasses are Stipagrostis amabilis, Eragrostis trichophora, Brachiaria glomerata, Stipagrostis uniplumis, S. ciliata, Centropodia glauca and Schmidtia kalahariensis. Rhigozum trichotomum dominates the whitish calcareous soils in the dune valleys and depressions. In these patches Harpagophytum procumbens, Jatropha erythropoda and Dipcadi gracillimum are the diagnostic species.

\section{Acacia erioloba-Acacia mellifera Parallel High Duneveld}

This open tree savanna (Fig. 5c) occurs widespread on the deep, reddish sand in the duneveld and near rivers and pans, mostly along a strip on the northern side of the Auob River and on both sides of the Nossob River from Samevloeiing in the south to Langklaas in the north. The landscape unit also occurs south of Grootkolk in the north. It is the third largest unit in the KGNP and covers an area of 175923 ha $(16.09 \%$ of the mapped area). The prominent woody species are Acacia erioloba, A. haematoxylon, Boscia albitrunca and Grewiaflava. Acacia mellifera is particularly prominent against north to northeast-facing slopes. The diagnostic species on the dune slopes are Searsia tenuinervis (= Rhus tenuinervis), Lycium bosciifolium, L. villosum 
and Ehretia alba. Conspicuous dwarf shrubs are Asparagus nelsii, Gnidia polycephala and Rhigozum trichotomum. The most common grass species include Schmidtia kalahariensis, Eragrostis lehmanniana, Centropodia glauca, Stipagrostis uniplumis and S. ciliata. Common herb species are Crotalaria sphaerocarpa, Pollichia campestris, Bulbostylis hispidula, Sesamum triphyllum, Limeum fenestratum, L. argute-carinatum and Cleome kalachariensis.

\section{B. Low dunes}

4. Acacia erioloba-Schmidtia kalahariensis Low Duneveld

This open tree savanna occupies 38993 ha $(3.57 \%$ of the mapped area) and occurs in the interior duneveld in the north in the vicinity of Loffiesdraai, Dankbaar, Gharagab and Bayip and west of the Nossob River near Grootbrak. The dunes are typically from $6 \mathrm{~m}$ to $9 \mathrm{~m}$ high in the interior and from $9 \mathrm{~m}$ to $15 \mathrm{~m}$ high along the rivers. The landscape is relatively species poor and is dominated by Acacia erioloba and Schmidtia kalahariensis (Fig. 6a). Other prominent woody species are Rhigozum trichotomum, Boscia albitrunca and Acacia mellifera and occasionally Searsia tenuinervis, Cadaba aphylla and Lycium spp. Terminalia sericea is locally prominent on the higher dunes. Besides Schmidtia kalahariensis, the grass layer is characterised by Eragrostis lehmanniana, Centropodia glauca, Stipagrostis amabilis, S. uniplumis, Brachiaria glomerata and Stipagrostis ciliata. Herbs that are found in this unit include Hermannia tomentosa, Hermbstaedtia fleckii, Requienia sphaerosperma, Pupalia lappacea, Chrysocoma obtusata, Cynanchum orangeanum and the climber Pergularia daemia.

Isolated patches of either Acacia luederitzii or Albizia anthelmintica occur on dunes and slopes within this unit in the northern parts of the park, especially west of the Nossob River in the vicinity of Grootbrak and Bayip Pan (Fig. 6b). Although many of these patches are too small to be mapped individually, the larger ones have been mapped (unit 4a in Fig. 2) and in total cover 532 ha $(0.05 \%$ of the mapped area). Other woody species associated with these patches include Acacia erioloba, A. mellifera, Boscia albitrunca and Grewia flava, with Schmidtia kalahariensis the dominant grass species.

\section{Acacia haematoxylon-Stipagrostis ciliata Irregular Low Duneveld}

This is the largest landscape unit in the park, covering an area of 243155 ha or approximately $22 \%$ of the mapped area (Fig. 2). It encompasses the grass-covered irregular dunes (Fig. 6c) in the southwestern section, east of Mata-Mata and north of the Auob River in the Strathmore, Nu Quap, Copeng and Lammermoor areas, as well as from the south to the far north in the eastern interior duneveld. A large number of pans are scattered throughout this landscape. Acacia haematoxylon is the most conspicuous woody species with Stipagrostis ciliata, Centropodia glauca and Stipagrostis amabilis the prominent grass species. Other widespread grass species in this unit include Stipagrostis uniplumis, Brachiaria glomerata, Schmidtia kalahariensis and Eragrostis lehmanniana. The forb layer is characterised by Requienia sphaerosperma, Sesamum triphyllum, Hermannia tomentosa, Plinthus sericeus, Oxygonum dregeanum and Limeum arenicolum. The prostrate cucurbits Citrullus lanatus and Acanthosicyos naudinianus are sometimes prominent.

The vegetation on the dune slopes often differs from that in the interdune valleys. The prominent woody species on the dune slopes are Acacia mellifera, Boscia albitrunca and Acacia haematoxylon with Centropodia glauca, Schmidtia kalahariensis, Eragrostis lehmanniana, Requienia sphaerosperma and Senna italica the conspicuous grass and forb species.

The prominent woody species in the grass-covered dune valleys on deep greyish to reddish sand are Acacia mellifera, Rhigozum trichotomum and Acacia haematoxylon. The more common grass and forb species include Stipagrostis uniplumis, Centropodia glauca, Eragrostis lehmanniana, Schmidtia kalahariensis, Chascanum pumilum, Hermannia burchellii, Senna italica, Limeum argute-

TABLE 1
Landscapes of the Kalahari Gemsbok National Park based on the dominant plant species, terrain morphology and soil types

TABLE 1
Landscapes of the Kalahari Gemsbok National Park based on the dominant plant species, terrain morphology and soil types

\begin{tabular}{|c|c|c|c|c|}
\hline & LANDSCAPE UNIT & AREA (HA) & $\%$ OF TOTAL AREA MAPPED & \% PER LANDSCAPE GROUP \\
\hline A. & High dunes & & & \\
\hline 1. & Acacia haematoxylon Parallel High Duneveld & 40950.8 & 3.75 & \\
\hline 2. & Acacia haematoxylon Irregular High Duneveld & 127532.4 & 11.67 & \\
\hline 3. & Acacia erioloba-Acacia mellifera Parallel High Duneveld & 175922.5 & 16.09 & 31.51 \\
\hline B. & Low dunes & & & \\
\hline 4. & Acacia erioloba-Schmidtia kalahariensis Low Duneveld & 38992.5 & 3.57 & \\
\hline $4 a$ & Acacia luederitzii or Albizia anthelmintica Patches & 532.3 & 0.05 & \\
\hline 5. & Acacia haematoxylon-Stipagrostis ciliata Irregular Low Duneveld & 243154.8 & 22.24 & \\
\hline 6. & Acacia haematoxylon-Centropodia glauca Undulating Low Duneveld & 182888.7 & 16.73 & 42.59 \\
\hline C. & Plains on deep reddish sand & & & \\
\hline 7. & Acacia haematoxylon-Stipagrostis amabilis Undulating Plains & 115478.9 & 10.56 & \\
\hline 8. & Stipagrostis amabilis Plains & 51198.5 & 4.68 & 15.24 \\
\hline D. & Calcretes & & & \\
\hline 9 & Calcrete Outcrops & 5826.1 & 0.53 & 0.53 \\
\hline E. & Plains and terraces along riverbeds and grass pans on compact whitish sand & & & \\
\hline 10 & Acacia erioloba-Rhigozum trichotomum-Stipagrostis obtusa River Terraces & 38763.8 & 3.55 & \\
\hline 11 & Acacia mellifera-Rhigozum trichotomum-Stipagrostis obtusa River Terraces & 34431.3 & 3.15 & \\
\hline 12 & Salsola spp.-Eriocephalus decussatus River Terraces and Pan Edges & 1593.7 & 0.15 & \\
\hline 13 & Stipagrostis obtusa River Terraces & 2667.3 & 0.24 & 7.09 \\
\hline F. & Riverbeds and pans & & & \\
\hline 14 & Sporobolus rangei Pan Floors & 3024.3 & 0.26 & \\
\hline 15 & Panicum coloratum Riverbeds & 6917.4 & 0.63 & \\
\hline 16 & Galenia africana-Lagerra decurrens Riverbeds & 6320.5 & 0.58 & \\
\hline 17 & Lebeckia linearifolia Riverbeds & 910.7 & 0.08 & \\
\hline 18 & Acacia erioloba-Acacia haematoxylon Riverbeds & 4350.6 & 0.40 & \\
\hline 19 & Grassy Pans & 10781.8 & 0.99 & 2.94 \\
\hline G. & Highly irregular dunes & & & \\
\hline \multirow[t]{2}{*}{20} & Highly Irregular Dunes & 917.1 & 0.08 & 0.08 \\
\hline & Total & 1093155.9 & 100.00 & 100.00 \\
\hline
\end{tabular}




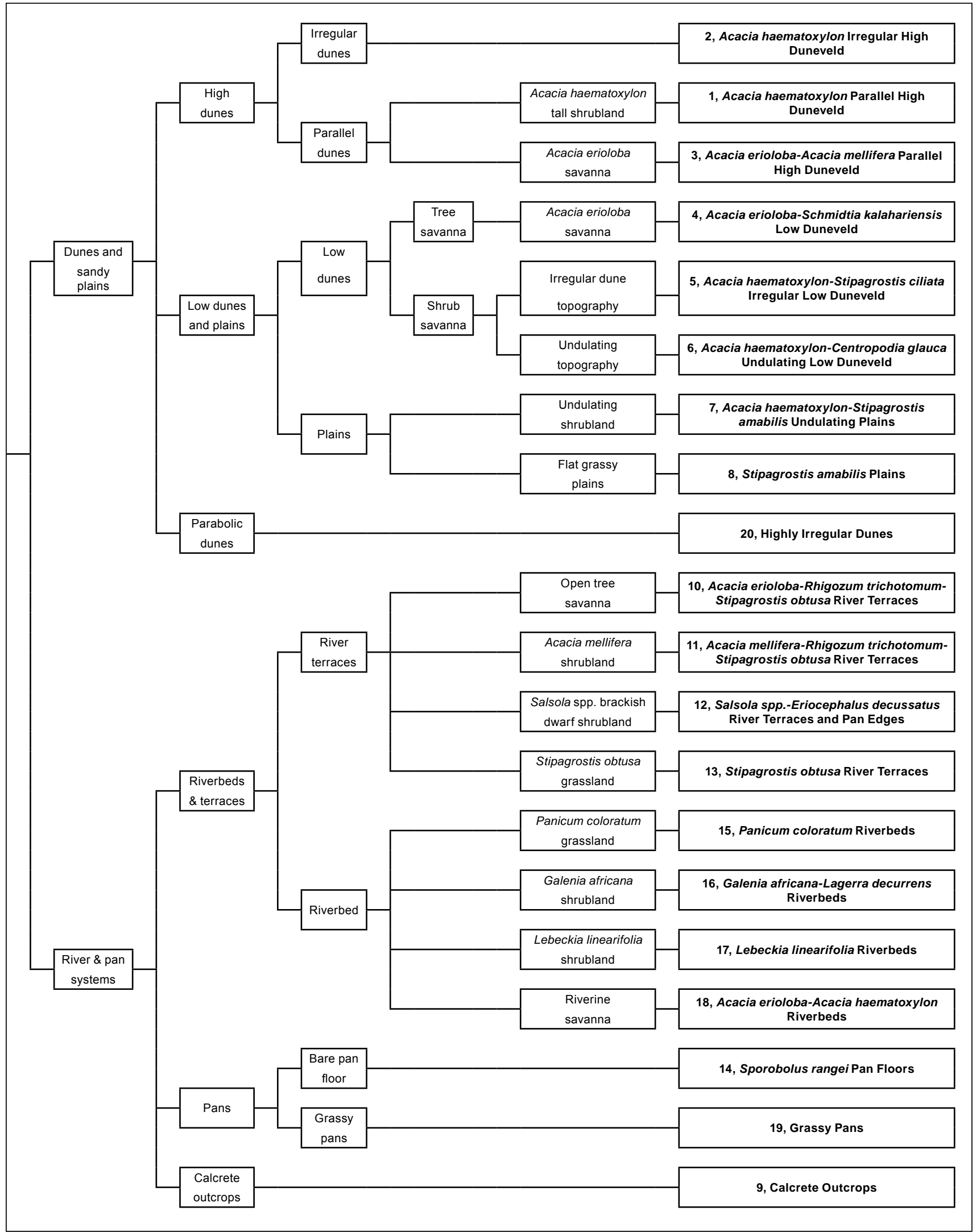

FIGURE 3

Relationships between the landscape units identified in the Kalahari Gemsbok National Park 


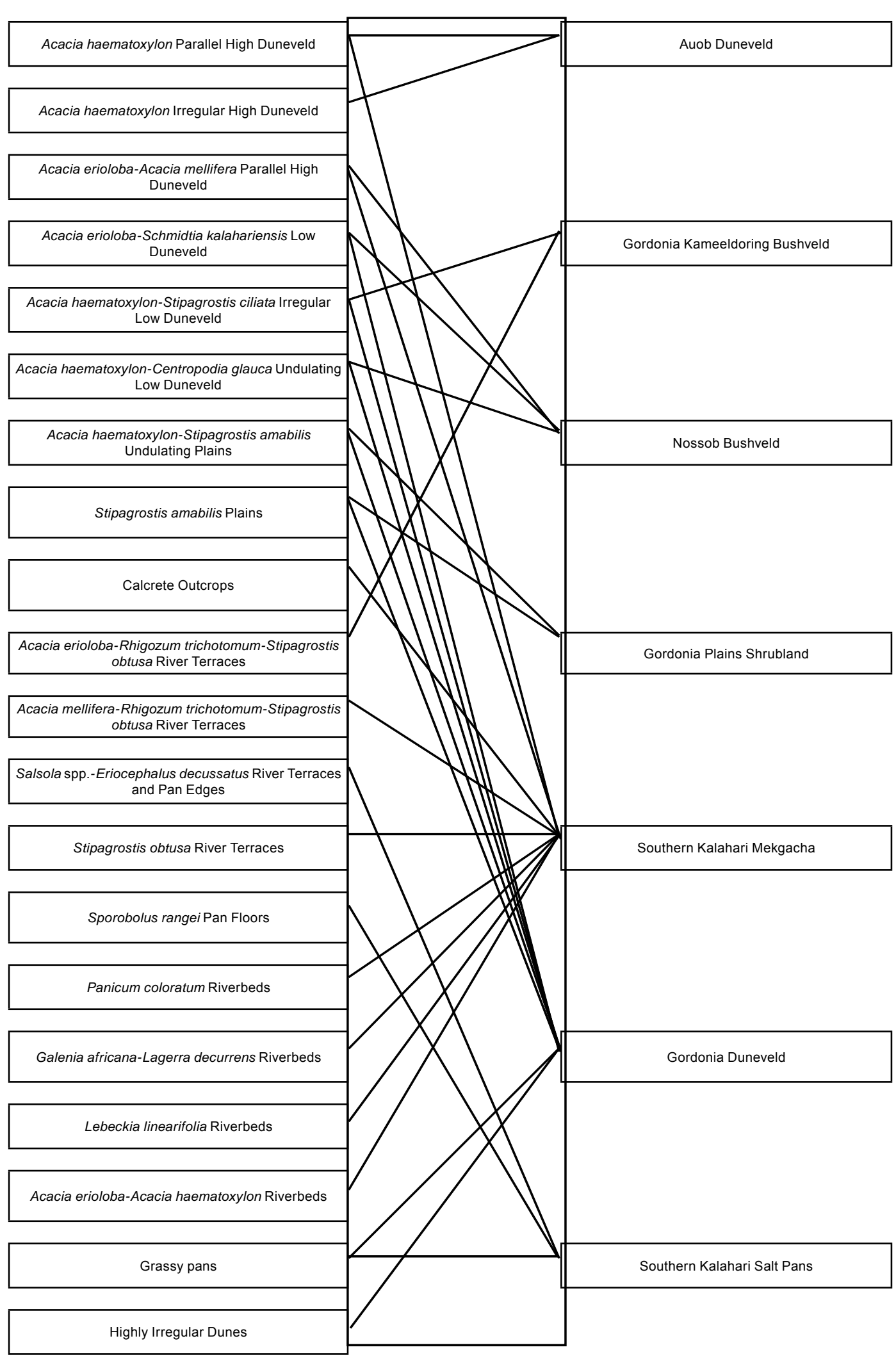

FIGURE 4

An overview of the correspondence between the present landscapes and the vegetation units in the latest vegetation map of South Africa by Mucina and Rutherford (2006) 

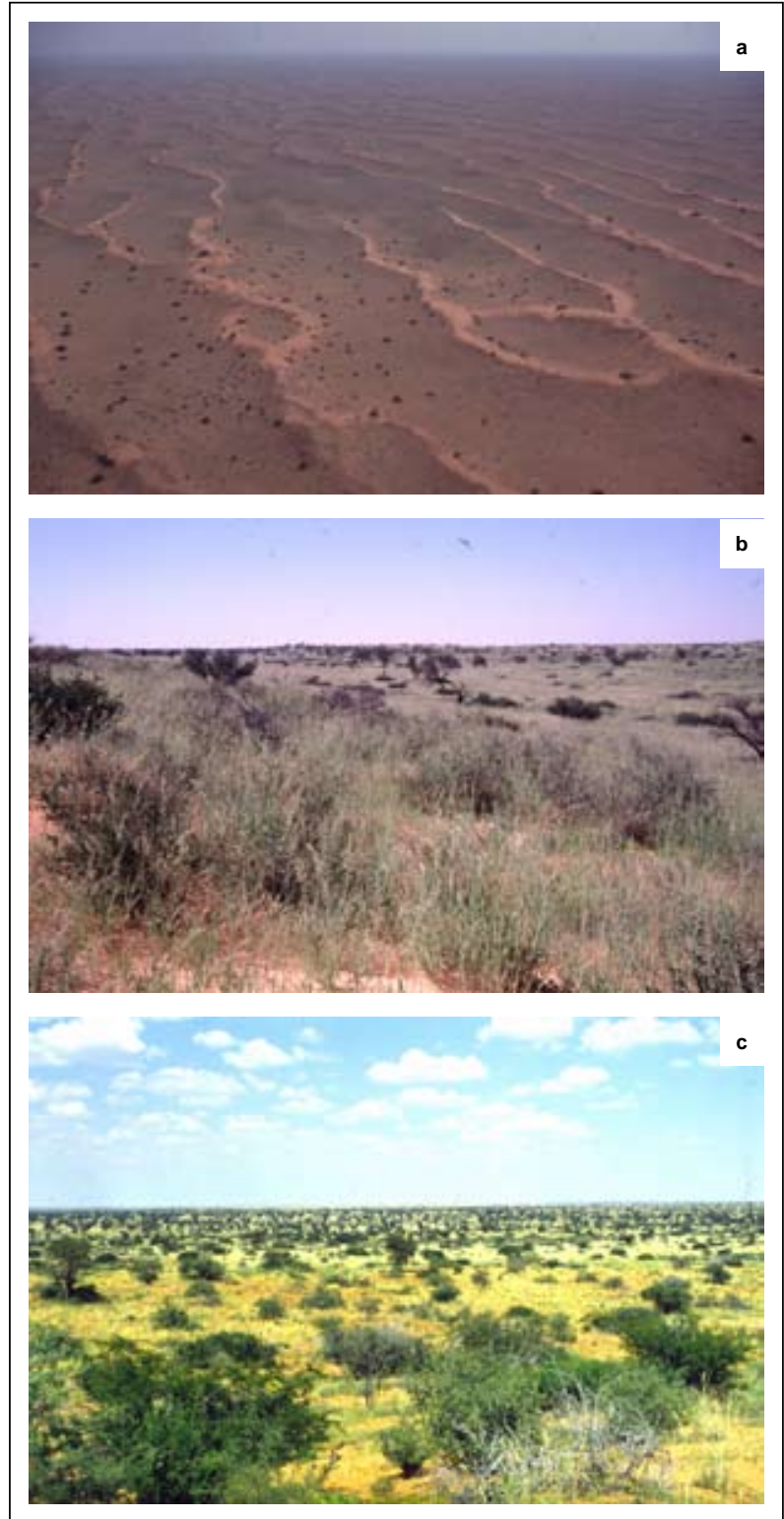

FIGURE 5

Landscapes of the high dunes: (a) the Acacia haematoxylon Parallel High Duneveld (A1); (b) the Acacia haematoxylon Irregular High Duneveld (A2); and (c) the Acacia erioloba-Acacia mellifera Parallel High Duneveld (A3) in a zone along the rivers

carinatum and Ipomoea hackeliana. In the dune valleys, near pans and rivers on slightly compact calcareous and whitish sand, open to dense stands of Rhigozum trichotomum, Monechma incanum and Stipagrostis obtusa dominate. Aptosimum albomarginatum, Talinum caffrum, Stipagrostis ciliata and Tribulus zeyheri are some of the other prominent species on these calcareous soils.

6. Acacia haematoxylon-Centropodia glauca Undulating Low Duneveld

This undulating shrubby grassland covers the second largest area in the KGNP (182 889 ha or $16.73 \%$ ) and occurs throughout the interior duneveld from Kij Gamies in the south to Union's End in the north. The prominent woody species in this undulating landscape are Acacia haematoxylon, Acacia erioloba and Boscia albitrunca, with Centropodia glauca, Aristida meridionalis, Schmidtia kalahariensis, Eragrostis lehmanniana and Stipagrostis uniplumis the conspicuous grass species (Fig. 6d). The characteristic dwarf shrubs and forbs include Requienia sphaerosperma, Chascanum pumilum, Hermannia burchellii, Limeum argute-carinatum, Ipomoea hackeliana, Chascanum garipense and Senna italica.
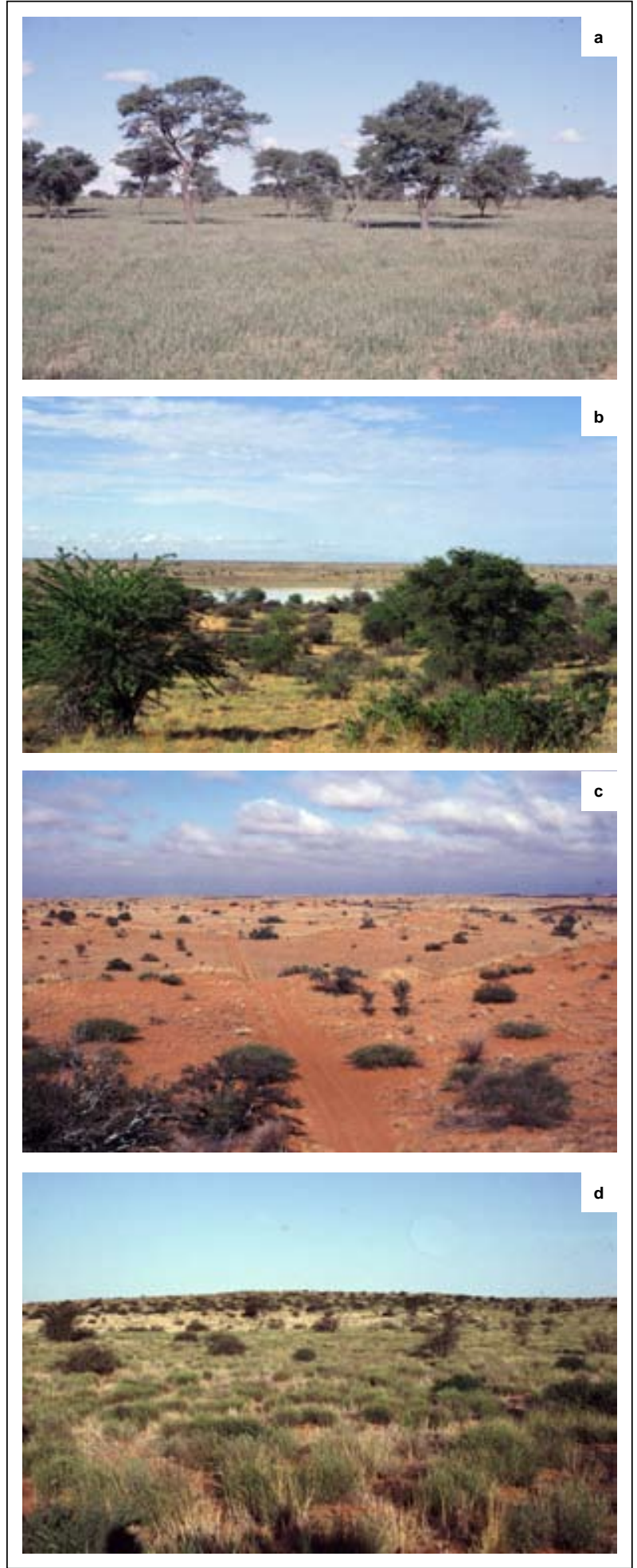

FIGURE 6 Landscapes of the low dunes: (a) the Acacia erioloba-Schmidtia kalahariensis
Low Duneveld (B4) near Loffiesdraai; (b) an Albizia anthelmintica Patch (B4a) around Bayip Pan; (c) the Acacia haematoxylon-Stipagrostis ciliata Irregular Low Duneveld (B5); and (d) the Acacia haematoxylon-Centropodia glauca Undulating Low Duneveld (B6)

\section{Plains on deep reddish sand}

7. Acacia haematoxylon-Stipagrostis amabilis Undulating Plains

This shrubby grassland on deep sand of gently undulating plains covers a large area (115 479 ha or $10.56 \%$ of the mapped area) and occurs in large patches from south to north throughout the interior duneveld. The dunes are not prominent, and if they occur they seldom reach $6 \mathrm{~m}$ in height. Acacia haematoxylon is the 
conspicuous woody species, usually as shrub, with Stipagrostis amabilis the most prominent grass species (Fig. 7a). Other grass species of note are Schmidtia kalahariensis, Centropodia glauca, Eragrostis lehmanniana, Stipagrostis uniplumis and Brachiaria glomerata. The most common dwarf shrubs and forbs include Requienia sphaerosperma, Bulbostylis hispidula, Acanthosicyos naudinianus, Citrullus lanatus, Hermannia tomentosa, Plinthus sericeus, Oxygonum dregeanum, Sesamum triphyllum and Limeum arenicolum.

\section{Stipagrostis amabilis Plains}

These flat, grassy plains (Fig. 7b) with scattered shrubs of Acacia haematoxylon are found in the central interior duneveld, with undulations of less than $2 \mathrm{~m}$. The unit covers $4.68 \%$ of the total mapped area (51 199 ha). The grass Stipagrostis amabilis is dominant together with prominent species such as Aristida meridionalis, Centropodia glauca, Eragrostis lehmanniana, E. pallens, Stipagrostis uniplumis and Brachiaria glomerata.

\section{Calcretes}

\section{Calcrete Outcrops}

The calcrete outcrops, terraces and floodplains along the Auob and Nossob rivers and at pans (Fig. 8) where whitish calcareous and compact sandy soils occur are characterised by a specific plant assemblage. This small unit covers only $0.53 \%$ of the mapped area (5 826 ha). Scattered individuals of Acacia erioloba A. mellifera, Boscia albitrunca, Lycium bosciifolium and Grewia flava occur in this unit, which is dominated by dwarf shrubs such as Rhigozum trichotomum, Monechma genistifolium subsp. australe, Zygophyllum pubescens, Ehretia alba, Leucosphaera bainesii, Plinthus cryptocarpus, Salsola tuberculata and Aizoon schellenbergii. The grass layer is poorly developed and is characterised by Enneapogon desvauxii, E. scaber, Stipagrostis hirtiglumma, Cenchrus ciliaris, Fingerhuthia africana, Stipagrostis ciliata, S. obtusa and the ever-present Schmidtia kalahariensis. Other prominent dwarf shrubs, forbs and succulents are Indigofera auricoma, Barleria rigida, Chamaesyce glanduligera, Ptycholobium biflorum, Tribulus zeyheri, Cleome angustifolia, Adenium oleifolium and Euphorbia braunsii.

\section{E. Plains and terraces along riverbeds and grass pans on compact whitish sand}

10. Acacia erioloba-Rhigozum trichotomum-Stipagrostis obtusa River Terraces

This landscape is characterised by scattered large Acacia erioloba trees on slightly compact, calcareous and whitish sand in the dune valleys, near pans and along the Auob and Nossob rivers throughout the park (Fig. 9a). It covers an area of 38764 ha (3.55\% of the mapped area). The most noteworthy woody species are Acacia erioloba, A. luederitzii, A. mellifera, Boscia albitrunca, Grewia flava, Searsia tenuinervis, Lycium bosciifolium, L. hirsutum and Ehretia alba. Open to dense stands of Rhigozum trichotomum, Monechma incanum and Aptosimum albomarginatum often develop. The dominant grass species are Stipagrostis obtusa, Schmidtia kalahariensis, Eragrostis lehmanniana, Stipagrostis ciliata and S. uniplumis. Herbs include Talinum caffrum, Requienia sphaerosperma, Sesamum triphyllum, Phyllanthus maderaspatensis, Limeum aethiopicum and Tribulus zeyheri.

\section{Acacia mellifera-Rhigozum trichotomum-Stipagrostis obtusa River Terraces}

This shrubland is related to unit 10 and can be found on calcareous terraces near pans and rivers throughout the park (Fig. 9b). It covers an area of 34431 ha (3.15\% of the mapped area). The dominant woody species in this unit is Acacia mellifera, with other less frequent woody species being Boscia albitrunca, Acacia erioloba, Grewia flava, Lycium bosciifolium, Searsia tenuinervis, Ehretia alba and Rhigozum trichotomum. The dominant grass
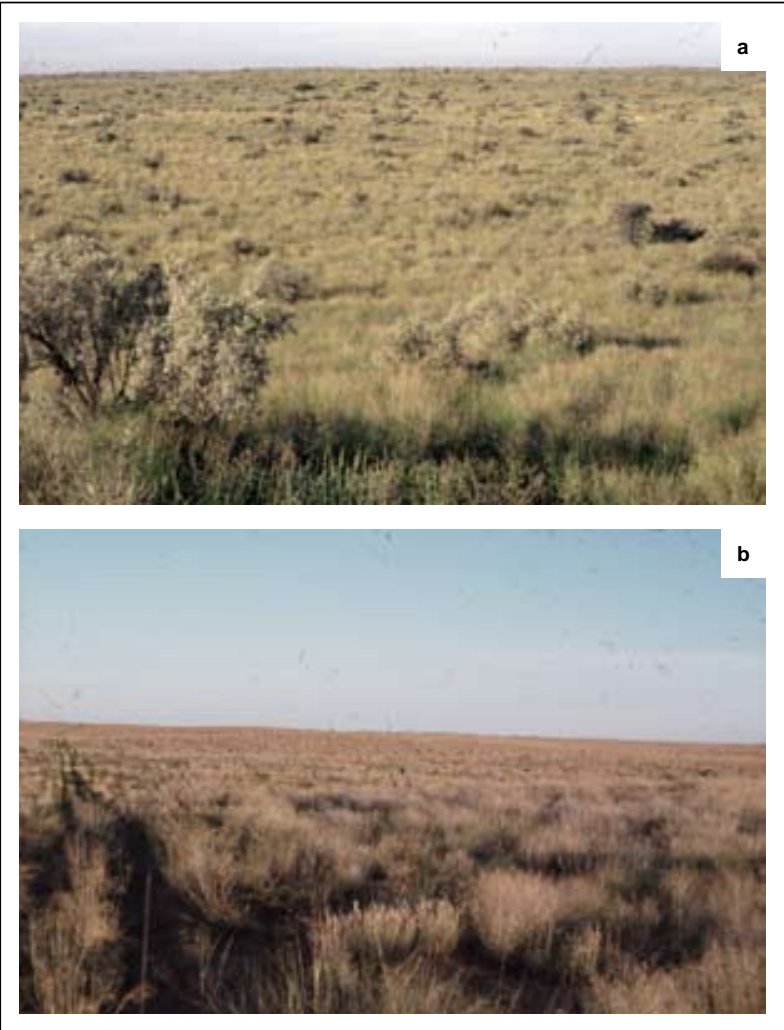

FIGURE 7

Landscapes of the plains on deep reddish sand in the interior duneveld: (a) the Acacia haematoxylon-Stipagrostis amabilis Undulating Plains (C7); and (b) the flat landscape of the Stipagrostis amabilis Plains (C8)

species are Stipagrostis obtusa, S. ciliata, Schmidtia kalahariensis and Stipagrostis uniplumis.

12. Salsola spp- Eriocephalus decussatus River Terraces and Pan Edges

This small unit is characterised by dwarf shrubs on the edges of pans and calcareous outcrops along the Nossob River and is well-developed in the vicinity of Polentswa (Fig. 9c). It covers an area of only 1594 ha, constituting $0.15 \%$ of the mapped area (Fig. 2). The diagnostic species are Salsola tuberculata, Eriocephalus decussata, Monechma genistifolium subsp. australe and Plinthus karrooicus. Other conspicuous species are Rhigozum trichotomum, Salsola etoshensis, Eriocephalus pubescens, Zygophyllum simplex, Leucosphaera bainesii, Hypertelis salsoloides, Pseudogaltonia clavata and Rosenia humilis. Grasses are represented by Enneapogon desvauxii, Stipagrostis obtusa, Eragrostis truncata, E. echinochloidea, Sporobolus rangei and Schmidtia kalahariensis.

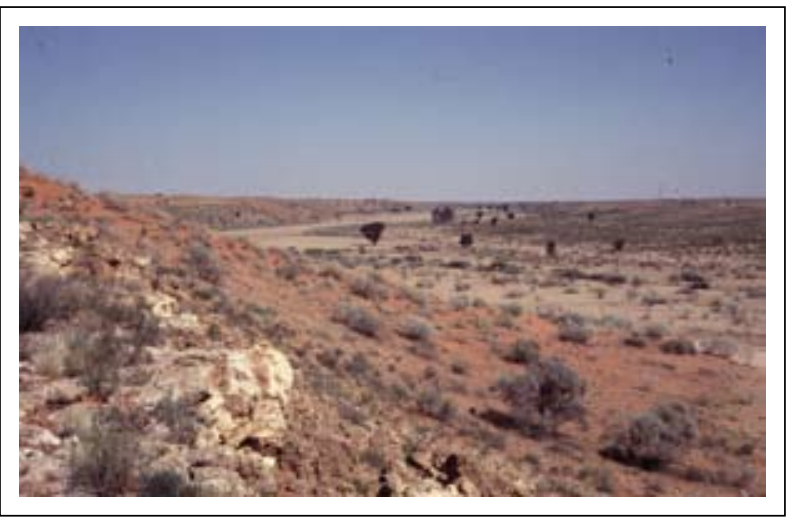

FIGURE 8

Calcrete Outcrop (D9) along the Nossob River. 


\section{Stipagrostis obtusa River Terraces}

This species-poor unit is characterised by an almost uniform and dense monoculture of the grass Stipagrostis obtusa and occurs locally on whitish, compact sandy soils on terraces and floodplains next to the Nossob River (Fig. 9d). Other infrequent species are Rhigozum trichotomum, Schmidtia kalahariensis, Gisekia africana and Eragrostis annulata. The unit covers 2667 ha $(0.24 \%$ of the mapped area).

\section{F . Riverbeds and pans}

14. Sporobolus rangei Pan Floors

Essentially two types of pan can be found, i.e. those with a bare pan surface (landscape 14) and grassy pans (landscape 19). Bare pan surfaces are commonly referred to as salt pans (Leistner 1967, Parris 1984, Van Rooyen 1984). They occur on whitish, calcareous, strongly alkaline and silty soils (Fig. 10a) and cover an area of 3024 ha $(0.28 \%$ of the mapped area). The vegetation of the pans differs noticeably from the surrounding savannas and often shows a concentric zonation. The vegetation of the pan floor and periphery is characterised by grasses such as Sporobolus coromandelianus, S. rangei, Eragrostis echinochloidea and Enneapogon desvauxii and dwarf shrubs such as Zygophyllum tenue, Salsola etoshensis, S. namaqualandica, Eriocephalus aspalathoides and Lycium cinereum. Further out from the pans is a zone of scattered trees of Acacia erioloba and Boscia albitrunca with dwarf shrubs such as Rhigozum trichotomum, Monechma incanum, M. genistifolium subsp. australe, Barleria rigida, Asparagus bechuanicus and Aptosimum albomarginatum. Prominent grass species in this zone include Eragrostis truncata, Tragus racemosa, Eragrostis porosa, Stipagrostis ciliata, S. obtusa and Schmidtia kalahariensis. Around some of the northern pans in the park, e.g. Bayip, stands of Albizia anthelmintica trees are prominent.

\section{Panicum coloratum Riverbeds}

This riverbed unit occurs especially in the northern parts of the Nossob River and is characterised by a dense grass stratum and large scattered trees of Acacia erioloba (Fig. 10b). It covers an area of 6917 ha ( $0.63 \%$ of the mapped area). The dominant grass species are Panicum coloratum, Eragrostis bicolor, Chloris virgata, Eragrostis rotifer, E. annulata, E. porosa, Schmidtia kalahariensis and Enneapogon desvauxii. The unit is rich in forb species, e.g. Cullen obtusifolia, Hermannia modesta, Cucumis africanus, Platycarpha carlinioides, Heliotropium lineare, Boerhavia repens, Stachys spathulata, Radyera urens, Cucumis africana, Aptosimum spinescens, Geigeria pectidea and G. ornativa. Setaria verticillata is a prominent grass species beneath trees in the riverbeds.

\section{Galenia africana-Lagerra decurrens Riverbeds}

This unit occurs locally in the Nossob riverbed from the confluence with the Auob River northwards to Nossob Camp and covers 6321 ha ( $0.58 \%$ of the mapped area). It is differentiated by the shrubs Galenia africana, Lagerra decurrens and Deverra denudata (Fig. 10c). Scattered Acacia erioloba trees occur while Chloris virgata, Panicum coloratum, Schmidtia kalahariensis and Eragrostis porosa are the prominent grass species.

\section{Lebeckia linearifolia Riverbeds}

In the lower Auob and Nossob rivers near Twee Rivieren the riverbed is dominated by the shrub Lebeckia linearifolia (Fig. 10d). This small unit covers only 911 ha ( $0.08 \%$ of the mapped area). Lebeckia linearifolia also occurs on dunes in landscape unit 1.
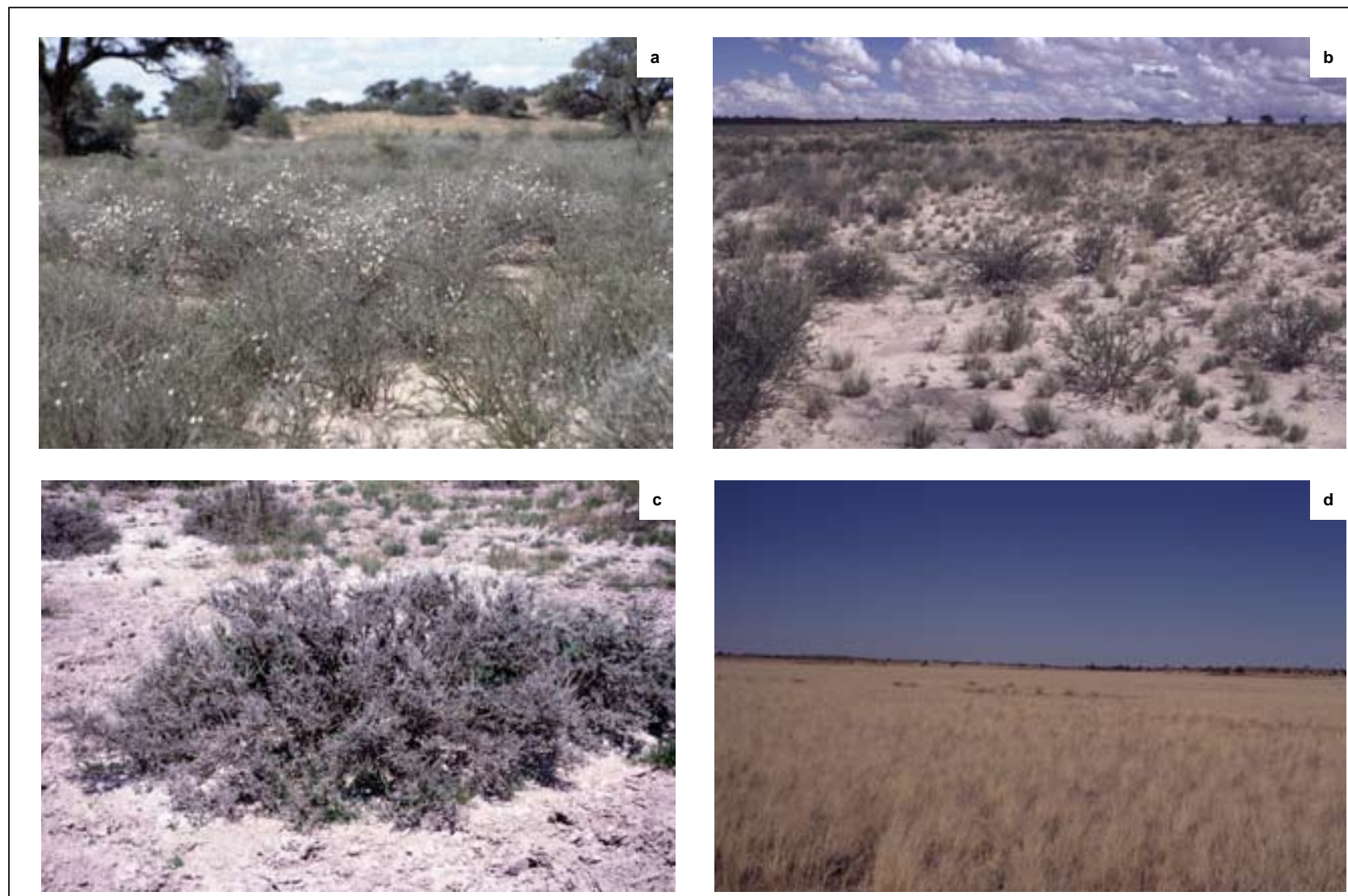

Landscapes of the plains and terraces along riverbeds and grass pans on compact whitish sand: (a) the Acacia erioloba-Rhigozum trichotomum-Stipagrostis obtusa River Terraces (E10) along the Nossob River; (b) the Acacia mellifera-Rhigozum trichotomum-Stipagrostis obtusa River Terraces (E11); (c) the Salsola spp.-Eriocephalus decussatus River Terraces and Pan Edges (E12); and (d) a monoculture of Stipagrostis obtusa on a Stipagrostis obtusa River Terrace (E13) 
18. Acacia erioloba-Acacia haematoxylon Riverbeds

This savanna occurs as a narrow zone on moderately compact calcareous sandy soils on the banks of the Auob River and occupies 4351 ha or $0.40 \%$ of the mapped area (Fig. 2). It is characterised by large trees of Acacia erioloba and A. haematoxylon (Fig. 10e) and the shrub Rhigozum trichotomum. The prominent grass species are Schmidtia kalahariensis, Stipagrostis obtusa and Eragrostis porosa, and the forb Tribulus zeyheri also occurs.

\section{Grassy Pans}

These pans occur throughout the park and in total they cover approximately $1 \%$ of the mapped area (10 782 ha) (Fig. 10f). These pans differ from the bare pans in having a lower concentration of minerals, mainly sodium chloride, on the pan floor (Parris 1984). The most prominent grass species are Sporobolus rangei, Stipagrostis ciliata, S. obtusa, Eragrostis echinochloidea, Enneapogon desvauxii, Eragrostis truncata, Tragus racemosa and Eragrostis

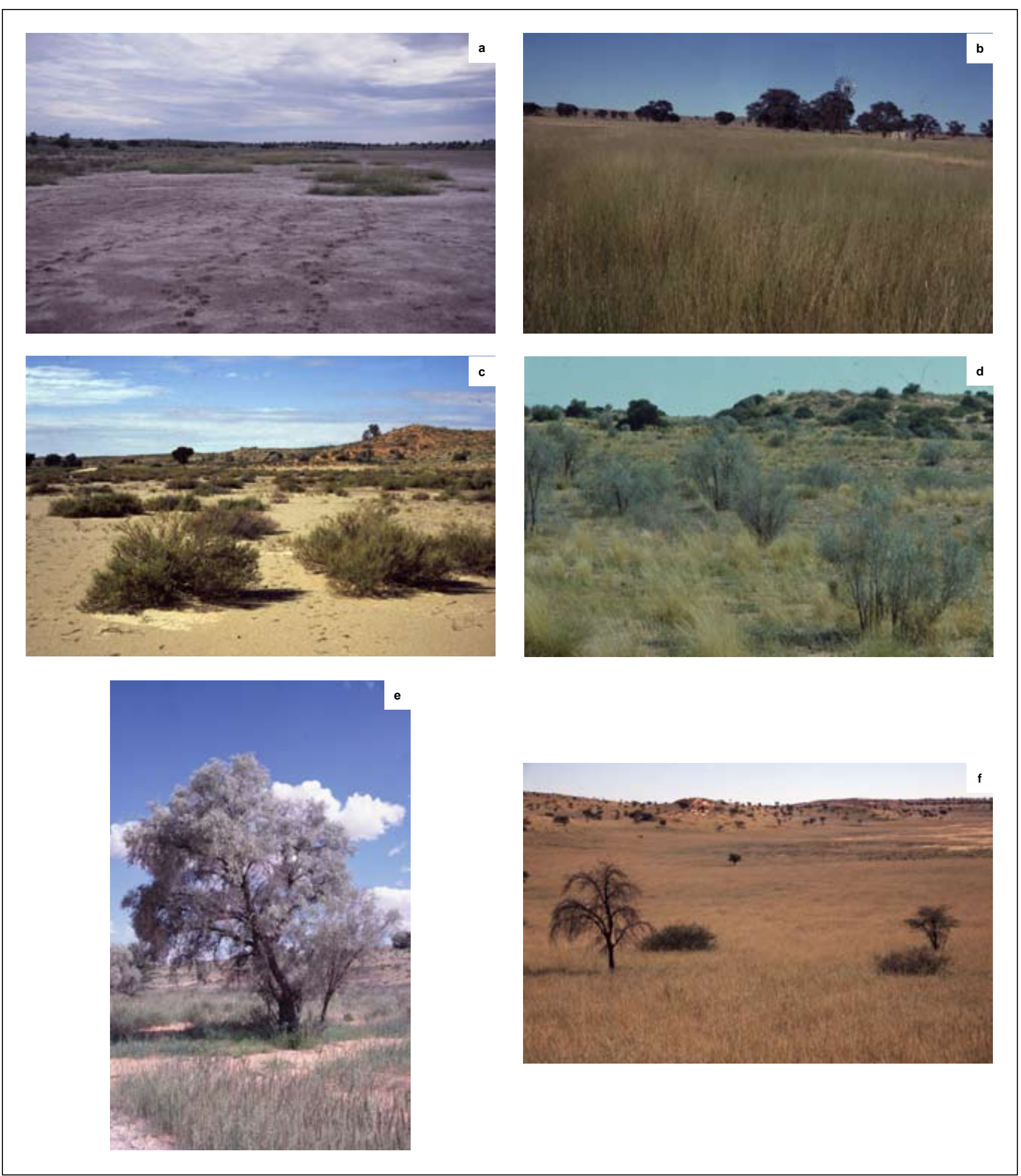

FIGURE 10

Landscapes of riverbeds and pans: (a) a Sporobolus rangei Pan Floor (F14); (b) the Panicum coloratum Riverbed near Kwang (F15); (c) the Galenia africana-Lagerra decurrens Riverbed (F16) near Leeudril; (d) a Lebeckia linearifolia Riverbed (F17); (e) a large Acacia haematoxylon in the Auob River in the Acacia erioloba-Acacia haematoxylon Riverbed (F18); and (f) an example of a Grassy Pan (F19) in the Kalahari 
porosa. This landscape is characterised by dwarf shrubs such as Salsola etoshensis, Eriocephalus pubescens, Zygophyllum simplex, Z. tenue, Rhigozum trichotomum, Hypertelis salsoloides and Rosenia humilis on the edge of pans. Forbs such as Aptosimum lineare, Trianthema parvifolia, Geigeria ornativa, Heliotropium lineare, Cucumis africanus and Indigofera alternans and geophytes such as Nerine laticoma and Pseudogaltonia clavata are found in this landscape.

\section{G. Highly irregular dunes}

\section{Highly Irregular Dunes}

This striking landscape with ellipsoidal parabolic dunes (Eriksson et al. 1989) is found in a few isolated patches in the interior duneveld of the park (Fig. 11). The unit covers only 917 ha $(0.08 \%$ of the mapped area) and is characterised by scattered trees and shrubs of Boscia albitrunca and Acacia mellifera. The prominent grass species include Stipagrostis amabilis, Eragrostis trichophora, Brachiaria glomerata and Schmidtia kalahariensis.

\section{DISCUSSION}

The whole area of the KGNP is fairly homogeneous and for the most part belongs to the Kalahari Duneveld Bioregion (Mucina \& Rutherford 2006), characterised by Acacia erioloba, Rhigozum trichotomum and Schmidtia kalahariensis. The vegetation structure is predominantly that of a shrubby grassland, except in the north and along the Auob and Nossob rivers where an open tree savanna is found. Topographically the area can be divided into dunes (dune crests and dune valleys); sandy plains with red to pinkish sand; and rivers (including terraces and calcrete outcrops) and pans on whitish, compact calcareous sand and clay. The vegetation on fine-textured soils, such as those found in the pans, frequently shows a Karroid nature (Leistner 1967).

The southern Kalahari is described as a floristically impoverished area. The homogeneity of the relatively recent sand deposits leads to reduced landscape differentiation and thus low niche differentiation. The Kalahari is therefore not a 'hotspot' in terms of plant species richness or rarity. The vegetation and landscapes around pans and along the rivers are the most diverse (Van Rooyen \& Van Rooyen 1998). However, there are a number of plant species that are of special interest in the KGNP. These species are all common and abundant species elsewhere but are of rare occurrence in the park. For example, Parkinsonia africana is known only by a small population that occurs in the lower Nossob River. Other woody species that are relatively rare in the park include Boscia foetida subsp. foetida on calcrete ridges in the south of the park, Cadaba aphylla, Diospyros austro-africana and Ehretia alba. A few individuals of Dichrostachys cinerea are found in the north near Grootbrak and Union's End in landscape unit 6. Likewise, Catophractes alexandrii is limited to the extreme northern part of the KGNP on calcrete ridges adjacent to the Nossob River, although it is abundant on the Botswana side of the Kgalagadi Transfrontier Park. Albizia anthelmintica and to a large extent also Acacia luederitzii have restricted distributions on the South African side of the Kgalagadi Transfrontier Park. Albizia anthelmintica reaches its southwestern distribution limit in South Africa in the park whereas Acacia luederitzii is one of the few species endemic to the Kalahari. Terminalia sericea is locally prominent on the higher dunes in the northern part of the park, especially in landscape unit 4 . The false camel thorn Acacia erioloba $x$ Acacia haematoxylon is relatively rare but is found in the southern parts of the park along the Auob and Nossob rivers. Woody species that have been recorded on the Botswana side of the Kgalagadi Transfrontier Park and not yet on the South African side include several Commiphora species, Grewia flavescens, Ochna pulchra, Vangueria infausta, Tylosema esculentum and Ziziphus mucronata. The shrub Phaeoptilum spinosum was recorded south of the park but not yet in the Kgalagadi Transfrontier Park.

The characteristic tree species in several of the landscapes, i.e. Acacia erioloba, Acacia haematoxylon and Boscia albitrunca, are

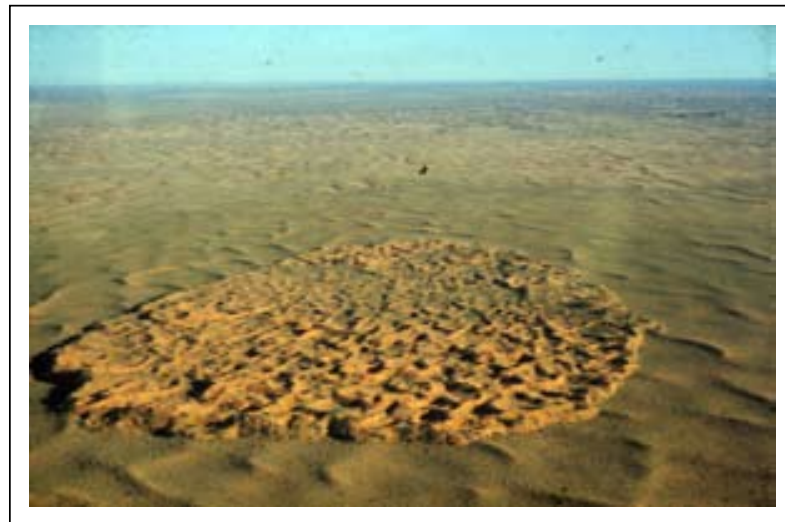

FIGURE 11

An isolated patch of ellipsoidal parabolic dunes or Highly Irregular Dunes (G21) in the Kalahari Gemsbok National Park

listed as protected trees through the National Forestry Act by the Department of Water Affairs and Forestry. Acacia erioloba is regarded as a keystone species and the survival of many other animal and plant species depends on it (Dean et al. 1999). Although wood harvesting, especially that of Acacia erioloba, is a serious problem outside the boundaries of the park, wood harvesting is not permitted inside the park.

Alien invasive plant species are not a big problem in the KGNP. Large Prosopis glandulosa trees occur in the camps but have not yet been noticed spreading into the natural vegetation. Other species that have been listed as invasive in the Kalahari environment include Prosopis chilensis, Verbesina enceloides and Argemone ochroleuca. The landscapes most prone to invasion by alien species are the riverbeds (landscapes 15 to 18).

The aims of the present map were to identify landscapes and their associated vegetation to assist in vegetation and animal conservation and tourist management. Landscapes that play an important role in the ecological relationships of the region include the calcretes, riverbeds and pans (landscape units 9 to 19). These landscapes cover only about $10 \%$ of the total area but are focal points for the large animals of the region (Parris 1970, 1984, Child et al. 1971, Bothma \& Mills 1977, Mills \& Retief 1984, Bergstrom \& Skarpe 1999). Most of the animal sightings are concentrated in the riverbeds and pans that cover less than $4 \%$ of the total area. The interior dunes and plains (landscape units 1 to 8 ) are usually used by wildlife only in the wet season when the food plants are not as nutrient deficient as during the dry season (Stapelberg 2007).

Although animals tend to congregate in the river systems, grazing impacts are localised and controlled by a natural rotational grazing system, with the availability and nutritional quality of food rather than water controlling animal numbers (Van Rooyen \& Van Rooyen 1998). The seasonal migratory movements of wildlife is essential to maintain good veld condition and ensures that a long-term ecological balance prevails, which should continue if the present large size of this conservation area is maintained (Van der Walt et al. 1984). Artificial water provision does affect some aspects of the ecology of the system (Van Rooyen et al. 1994), but these watering points are deemed necessary from a tourist point of view (Knight \& Knight-Eloff 1988). The landscapes most affected by artificial water provision are landscapes 9 to 18 .

One of the major uses envisaged for the present landscape map is that it would serve as basis for planning monitoring programmes. Aspects of the vegetation that need to be monitored include the following:

- veld condition and the ecological capacity for large herbivores within each landscape;

- the impact of the provision of artificial watering points on landscapes 9 to 18 ; 
- trends in population density, frequency and cover of possible encroacher plant species, e.g. Rhigozum trichotomum, Acacia mellifera and Geigeria ornativa (all landscapes);

- the population structure of keystone species such as Acacia erioloba, Acacia haematoxylon, Acacia luederitzi and Boscia albitrunca; and

- the occurrence of alien plant species such as Prosopis spp. and Argemone ochroleuca in the riverbeds and pans (landscapes 10 to 19).

These monitoring efforts should determine the dynamics and trends of the ecosystem attributes and the extent to which the conservation objectives are being met. Geographic information systems (GIS) would be an ideal tool for managing such spatially related databases (Kotzé \& Fairall 2006). It is imperative that the results of monitoring be used to adapt management policies when necessary. By basing the monitoring efforts on the present landscape units, this map will assist in resource management that is based on the inherent ecological capacity of the ecosystem

\section{ACKNOWLEDGEMENTS}

We gratefully acknowledge the assistance of South African National Parks and specifically Dries Engelbrecht, Nico van der Walt, Nardus du Plessis and Hugo Bezuidenhout. Johan Kriek and the Van Rooyen family assisted with the field work.

\section{REFERENCES}

Acocks, J.P.H. 1953. Veld types of South Africa. Memoirs of the Botanical Survey of South Africa, 57: 1-146.

Bergström, R. \& Skarpe, C. 1999. The abundance of large wild herbivores in a semi-arid savanna in relation to seasons, pans and livestock. African Journal of Ecology, 37(1): 12-26.

Bothma, J. du P. \& De Graaff, G. 1973. A habitat map of the Kalahari Gemsbok National Park. Koedoe, 16: 181-188.

Bothma, J. du P. \& Mills, M.G.L. 1977. Ungulate abundance in the Nossob River Valley, Kalahari Desert. Proceedings of the XIIIth International Congress of Game Biologists, Atlanta, pp. 90-102.

Bothma, J. du P. \& Swart, D.R. 1990. Landsat-based remapping of the southwestern Kalahari. Koedoe, 33: 89-93.

Bothma, J. du P., Van Hoven, S. \& Le Riche, E.A.N. 1993. GPS corrected and GIS based remapping of the Kalahari Gemsbok National Park and the adjacent area in Botswana. Koedoe, 36: 105-108.

Brynard, A.M. 1958. Verslag insake voorlopige ondersoek rakende toestande in die Nasionale Kalahari-Gemsbokpark. Koedoe, 1: 162-183.

Child, G., Parris, R. \& Le Riche, E. 1971. Use of mineralised water by Kalahari wildlife and its effects on habitats. East African Wildlife Journal, 9(1): 125-142.

Coetzee, B.J. \& Werger, M.J.A. 1975. An east-west transect through Africa south of the Tropic of Capricorn. Bothalia, 11: 539-560.

Dean, W.R.J., Milton, S.J. \& Jeltsch, F. 1999. Large trees, fertile islands and birds in arid savanna. Journal of Arid Environments, 41(1): 61-78.

Eriksson, P.G., Nixon, N. Snyman, C.P. \& Bothma, J. du P. 1989. Ellipsoidal parabolic dune patches in the southern Kalahari Desert. Journal of Arid Environments, 16: 111-124.

Gertenbach, W.P.D. 1983. Landscapes of the Kruger National Park. Koedoe, 26: 9-21.

Giess, W. 1971. A preliminary vegetation map of South West Africa. Dinteria, 4: 5-114.

Gubb, A. 1980. Vegetation map of the Kalahari Thornveld Unpublished mimeograph. Kimberley: McGregor Museum.

Knight, M.H. \& Knight-Eloff, A.K. 1988. The importance of borehole water and lick sites for Kalahari South Africa ungulates. Journal of Arid Environments, 15: 269-282.
Kotze, I.J.D.F. \& Fairall, N. 2006. Using Landsat TN imagery to map fynbos plant communities: a case study. Journal of Wildlife Research, 36: 75-87.

Leistner, O.A. 1959a. Notes on the vegetation of the Kalahari Gemsbok National Park with special reference to its influence on the distribution of antelopes. Koedoe, 2: 128151.

Leistner, O.A. 1959b. Preliminary list of plants found in the Kalahari Gemsbok National Park. Koedoe, 2: 152-172.

Leistner, O.A. 1967. The plant ecology of the southern Kalahari. Memoirs of the Botanical Survey of South Africa, 38: 1-172.

Leistner, O.A. \& Werger, M.J.A. 1973. Southern Kalahari phytosociology. Vegetatio, 28(5/6): 353-397.

Low, A.B. \& Rebelo, A.G. 1998. Vegetation of South Africa, Lesotho and Swaziland. Pretoria: Department of Environmental Affairs and Tourism

Lubbinge, J.W. 1999. ' $n$ Fitososiologiese studie van die suidelike Kalahari duineveld. M.Sc. dissertation. Pretoria: University of Pretoria.

Mills, M.G.L. \& Retief, P.F. 1984. The response of ungulates to rainfall along the riverbeds of the southern Kalahari. Koedoe (Suppl.), 27: 129-141.

Mostert, J.W.C., Roberts, B.R., Heslinga, D.F. \& Coetzee, P.G.F. 1971. Veld management in the OFS region. Pretoria: Government Printer.

Mucina, L. \& Rutherford, M.C. 2006. The vegetation of South Africa, Lesotho and Swaziland. Strelitzia, 19, Pretoria: South African National Biodiversity Institute.

Mucina, L., Rutherford, M.C. \& Powrie, L.W. 2005. Vegetation map of South Africa, Lesotho and Swaziland. Pretoria: South African National Biodiversity Institute.

Parris, R. 1970. Important role of the Kalahari pans. African Wildlife, 24: 234-237.

Parris, R. 1984. Pans, rivers and artificial waterholes in the protected areas of the south-western Kalahari. Koedoe (Suppl.), 27: 63-82.

Pole-Evans, I.B. 1936. A vegetation map of South Africa. Memoirs of the Botanical Survey of South Africa, 15: 1-23.

Skarpe, C. 1986. Plant community structure in relation to grazing and environmental changes along a north-south transect in the western Kalahari. Vegetatio, 68: 3-18.

Stapelberg, F.H. 2007. Feeding ecology of the Kalahari springbok Antidorcas marsupialis in the Kgalagadi Transfrontier Park, South Africa. MSc dissertation, Pretoria: University of Pretoria.

Story, R. 1958. Some plants used by the Bushmen in obtaining food and water. Memoirs of the Botanical Survey of South Africa, 30: 1-155.

Thomas, D.S.G. \& Shaw, P.A. 1991. The Kalahari environment. Cambridge: Cambridge University Press.

Tyson, P.D. 1986. Climatic change and variability in southern Africa. Cape Town: Oxford University Press.

Van der Walt, P.T., Retief, P.T., Le Riche, E.A.N., Mills, M.G.L. \& De Graaff, G. 1984. Features of habitat selection by large herbivorous mammals and the ostrich in the southern Kalahari conservation areas. Koedoe (Suppl.), 27: 119-128.

Van Rooyen, N. 1996. Phytosociology, vegetation dynamics and conservation of the southern Kalahari. Unpublished report on a project executed on behalf of the Department of Environmental Affairs and Tourism. Pretoria: University of Pretoria.

Van Rooyen, N. 2000. Vegetation survey of the Gemsbok National Park, Botswana and mapping of the Kgalagadi Transfrontier Park. Stellenbosch: Peace Parks Foundation.

Van Rooyen, N., Bezuidenhout, D.J., Theron, G.K. \& Bothma, J. du P. 1990. Monitoring of the vegetation around artificial watering points (windmills) in the Kalahari Gemsbok National Park. Koedoe, 33: 63-88.

Van Rooyen, N., Bredenkamp, G.J., Theron, G.K., Bothma, J. du P. \& Le Riche, E.A.N. 1994. Vegetation gradients around artificial watering points in the Kalahari Gemsbok National Park. Journal of Arid Environments, 26: 349-361. 
Van Rooyen, N., Van Rensburg, D.J., Theron, G.K. \& Bothma, J. du P. 1988. A check list of flowering plants of the Kalahari Gemsbok National Park. Koedoe, 31: 115-135.

Van Rooyen, N. \& Van Rooyen, M.W. 1998. Vegetation of the southwestern arid Kalahari: an overview. Transactions of the Royal Society of South Africa, 53(2): 113-140.

Van Rooyen, T.H. 1984. The soils of the Kalahari Gemsbok National Park. Koedoe (Suppl.), 27: 45-62.
Werger, M.J.A. 1986. The Karoo and southern Kalahari. In: Evenari, M., Noy-Meir, I. \& Goodall, D.W. (eds.). Hot desert and arid shrublands. Amsterdam: Elsevier, pp. 283-359.

Werger, M.J.A. \& Coetzee, B.J. 1978. The Sudano-Zambezian region. In: Werger, M.J.A. \& Van Bruggen, A.C. (eds.). Biogeography and ecology of southern Africa. The Hague: Junk, pp. 301-462 